\title{
IAMJ
}

INTERNATIONAL

AYURVEDIC

MEDICAL JOURNAL

ISSN: 2320-5091

Impact Factor: 6.719

\section{CLASSICAL CONCEPT OF COOKING RICE: A SYSTEMATIC REVIEW}

\author{
Ketaki Hemant Patil ${ }^{1}$, Vidya Wasnik $\left(\right.$ Thatere) $^{2}$, Sumeeta S. Jain ${ }^{3}$ \\ PG scholar, department of Swasthavritta and Yog \\ Associate Professor, Department of Swasthavritta and Yog \\ HOD, department of Swasthavritta and Yog \\ Government Ayurved College, Nagpur, Maharashtra, India \\ Corresponding Author: ketakipatil0707@gmail.com
}

\section{https://doi.org/10.46607/iamj2009082021}

(Published Online: August 2021)

Open Access

(C) International Ayurvedic Medical Journal, India 2021

Article Received: 02/07//2021 - Peer Reviewed: 11/07/2021 - Accepted for Publication: 15/07/2021

\section{Check for updates}

\begin{abstract}
Ayurveda's foremost aim is prevention of diseases and then cure of diseases. Rice is the staple food of most of the Indians where it's faulty cooking methods is one of the main and unrecognised reasons for the development of various lifestyle diseases like obesity, Type 2 Diabetes Mellitus, etc. The method of removing the gruel from the cooked rice is well explained by Ayurvedic Samhitas. This method makes the rice Laghu i.e. light to digest and removes excess starch from the rice in the form of gruel. This reduces the glycemic index of the rice making it suitable for regular consumption. Due to this, obesity, and other lifestyle disorders like T2DM can be prevented leading to a disease-free life. The purpose of this article is to guide with the correct method of cooking rice according to Ayurvedic literature.
\end{abstract}

Keywords: Rice, Cooking, Glycemic index, Obesity, lifestyle, Ayurveda

\section{INTRODUCTION}

Ahar (food) is one of the main pillars called Trayopasthambha according to Ayurveda ${ }^{[1]}$. Acharya Charak had mentioned that one should consume wholesome food which not only imparts health but also prevents the future development of diseases ${ }^{[2]}$. Rice is the staple food of India especially in some areas like Southern India, coastal areas like Kerela, Konkan, etc. It is the second most widely consumed cereal in the world next to wheat ${ }^{[3]}$. Rice is the only cereal that is eaten as whole grain and according to Ayurveda, whole grain is more easily digestible than flour. There are many beliefs that rice is heavy to digest and should be avoided by obese and diabetic patients. In Asian populations, white rice makes large contributions to 
dietary glycemic load, an index reflecting the acute blood glucose-raising potential of foods or diets ${ }^{[4]}$. This leads to the development of various metabolic disorders like Type 2 Diabetes Mellitus, heart diseases etc.

This is because of lack of knowledge of basic concepts of cooking rice which leads to unhealthy or faulty cooking practices which increase the Kleda and Guruta of rice and lead to obesity and other diseases. Ancient Ayurveda has already described the authentic method of cooking rice. But due to increasing urbanisation, hasty life and increasing influence of western countries, various unnecessary changes are made in the cooking and dietary patterns. Ancient Indians were free from diabetes even after consuming rice as their main food. But today India is emerging as the diabetic capital of the world. Ayurveda has described the unique way of cooking rice which not only makes it easy to digest but also prevents obesity and other diseases. The following article illustrates the correct method of cooking rice.

Cause of Prameha: Navanna: According to Ayurveda, Prameha is caused due to consumption of $\mathrm{Na}$ vanna (new grains especially new rice and its products) ${ }^{[5]}$. Prameha is typically characterised by Prabhutavila Mutrata i.e., increased frequency and quantity of micturition ${ }^{[6]}$. New rice is typically Mutral and Abhishyandi and vitiates Kapha Dosha which leads to Prameha $^{[7]}$. So, if we can reduce the tendency of rice to produce Kleda, Prameha and obesity can be avoided. A meta-analysis of prospective cohort studies showed that higher white rice consumption was associated with a significantly elevated risk of type 2 diabetes where each serving per day of white rice consumption was associated with an $11 \%$ increase in the risk of diabetes in the overall Asian population ${ }^{[8]}$.

Selection of rice: Acharya Sushrut has described that Shashtik rice and Raktashali are best among Dhanya $^{[9]}$. According to Acharya Sushrut, Shashtik rice has Madhur Rasa (Sweet) with Kashay Anurasa (Astringent), is Laghu (light to digest), Mrudu (soft), Snigdha (unctuous), Grahi (absorbent) and alleviates the Tridoshas ${ }^{[10]}$. It takes 60 days to harvest this rice where both brown and yellow varieties are grown in
India. Acharya Sushrut has mentioned that the consumption of new grains (especially rice) is the main cause of Prameha. Therefore, he has been advised to consume old rice for about one year which becomes light to digest ${ }^{[7]}$. So instead of using new rice, it should be stored for 1 year and then use as old rice as it has less water content in it and is easy to digest. New rice already contains water and by cooking it in a pressure cooker, the water content in it increases greatly leading to Kledavriddhi and Abhishyandata which is the main cause of obesity and Prameha. One should consume the grains and vegetables grown in their local region as the weather conditions and the area in which those grains are cultivated are Satmya to the body composition of the people living in that area. So, any red or white (if red not available) unpolished rice which is at least one year old, grown in fewer days and organically without the use of excessive pesticides, cultivated in their local or native areas and wisely roasted before cooking is suitable for daily consumption ${ }^{[11]}$.

Polishing of rice: Polished rice undergoes the milling process which separates the husk, bran, the aleurone layer and embryo (germ) leaving behind a bowl of clean rice aka starchy endosperm which is a principal source of calories. This rice is low in fibre, polyphenols, and micronutrients such as magnesium which help in glucose metabolism and is heavier to digest, has a high glycemic index (GI) and glycemic load (GL), reflecting high postprandial blood glucose levels [12].

How to determine new v/s old rice?: New rice can be broken easily as it contains water but in old rice, water content is decreased so it can't be broken easily. The stored rice cooks better than a fresh crop. When stored for over 1 year it becomes well dehydrated, and on cooking, absorbs about the double quantity of water; grains remain separate, making the dish attractive when served.

Process of cooking: According to Acharya Sushrut, the Vishada (unpolished) rice, which is properly washed, and the gruel $(P e j)$ separated after cooking and which is hot while serving is Laghu (light to digest) ${ }^{[13]}$. While the rice which is not properly washed, 
cooked and the gruel is not separated after cooking and is cold while serving is Guru (heavy to digest).

1. Roasting: The rice which is roasted before cooking is light to digest, Kaphaghna and Sugandhi (with a specific fragrance) ${ }^{[14]}$. According to a recent study, there was a lower lipid content in the rice bran roasted for 15 minutes compared with the content of raw rice bran and increased levels of soluble, insoluble and total dietary fibre in roasted rice bran samples, which could be explained by the short hydrolysis and decomposition of Triglycerides with consequent release of fatty acids and formation of volatile compounds accountable for the aroma after a longer roasting time ${ }^{[15]}$.

2. Sudhauta: It should be well washed before cooking to remove the dirt present in it. According to Kaiyadev Nighantu, when rice is washed about 3 times it becomes easier to digest and ignites the digestive fire ${ }^{[16]}$. It is also very common in our tradition that washed rice when soaked for 15-20 minutes, cooks quickly.

Tandulodak: The water left after washing for the $3^{\text {rd }}$ time and $4^{\text {th }}$ time should not be thrown away as it is very healthy and nutritious according to Ayurveda. It is called Tandulodak which is used as Anupana with many Ayurvedic medicines. According to Bhaishajyaratnavali, it is a Heema Kalpana and is prepared by adding 8 times water and washing the rice ${ }^{[17]}$. It is one of the treatments for white discharge (Shwetapradara) and many gynaecological disorders.

3. Prasrut: It means that the gruel $(P e j)$ should be separated after the rice is cooked i.e. the supernatant liquid portion is drained out and the remnant solid portion is called Odana (rice) ${ }^{[18]}$. To cook the rice, about 10 parts of water is allowed to boil. After that, one part of washed rice is added to it and is cooked ${ }^{[18]}$. So, when the rice is cooked to about $90 \%$, as it is traditionally said in Maharashtra - Shitavarun Bhatachi Pariksha, the excess water which is called $P e j$ (gruel) should be taken away. This liquid starch solution is a combination of water and the outer layer of rice which is rich in vitamins and micronutrients. Instead of throwing this valuable starch solution down the drain, it is used constructively: half is offered to animals and plants, while the other half is inoculated with buttermilk and a pinch of fenugreek seeds - apparently because the strain of yeast that grows on fenugreek seeds is of particular value - and fermented overnight. The following day it is added to the pot in which the day's rice is being cooked ${ }^{[19]}$. It can also be given to children by adding some Asafoetida and Saindhav to it. It nourishes and strengthens the immune system. During this whole cooking process, the rice should not be covered with a lid. But now the almost cooked rice is covered with a lid and the steam inside the rice cooks it well. This is called Srut Odana which is very light to digest.

Pressure cooker: In recent times, the use of pressure cookers for the preparation of rice has increased. Cooking rice under high pressure and temperature reduces cooking time by half and saves fuel. It cooks by expelling air from the vessel and trapping the steam produced from the boiling rice inside. This raises internal pressure and permits a high cooking temperature essential for cooking. So, the traditional method of removing the gruel has been stopped due to which the GI of rice increased making it heavy to digest and prone to diabetes.

\section{DISCUSSION}

White rice has a shorter minimum cooking time and higher volume expansion than brown rice, indicating that white rice is more easily hydrated and gelatinised compared with brown rice, and therefore more readily digested and completely absorbed from the intestine, as the polished grain is not covered with cellulose resulting in a higher PPG response when cooked under the same conditions ${ }^{[20]}$. Acharya Charak has already advised consuming Purana Shalyodana in Prameha Chikitsa $^{[21]}$. During the cooking, a process called gelatinisation in the starch takes place which increases the glycemic index of rice. So, the more the rice is cooked, the more GI it has. But according to the Ayurvedic method, rice is added to already boiling water due to which rice is cooked early. Thus, after decanting the cooked rice, the excess starch is separated from the rice in the form of gruel reducing the GI of the rice. 
This reduces the blood sugar levels by reducing the easy availability of most soluble carbohydrates, reduces Kapha and constipation which will tend to improve long term colon health, and all conditions involving Ama. It also improves the vitamin content from the lactobacillus and yeast (killed by the cooking) which increases its nutritive value ${ }^{[19]}$. This method is exactly opposite to the current method of cooking the rice in a pressure cooker where the rice is boiled without draining the supernatant water portion which is nutritive but increases Kapha Dosha and is heavy to digest. Such rice can be called Aprasruta Odana. According to a recent study, the $200 \mathrm{ml}$ of pressurecooked rice contained $30 \mathrm{kcal}$ higher in calories than the same amount of non-pressure-cooked rice ${ }^{[22]}$. Therefore, it is always suggestible to cook rice by this classical method for long term health benefits.

\section{CONCLUSION}

Thus, instead of just stopping the consumption of rice with the fear of gaining weight or consuming calories, even by changing or adapting the Ayurvedic way of cooking rice, the development of lifestyle disorders like obesity and diabetes can be prevented.

\section{REFERENCES}

1. Garde GK. Sartha Vagbhat, Sutrasthan, Annarakshadhyay, Chapter 7, Verse 52. Varanasi: Chaukhamba Surbharti Prakashan, 2012; p.39

2. Tripathi B. Charak Samhita of Agnivesa, Part-1, Sutrasthan; Matrashitiya, Chapter 5, Verse 13. Varanasi: Chaukhamba Sanskrit Prakashan, 2004; p.108

3. Amanullah, Khan S-u-T, Iqbal A and Fahad S (2016) Growth and Productivity Response of Hybrid Rice to Application of Animal Manures, Plant Residues and Phosphorus. Front. Plant Sci. 7:1440

4. Mohan V, Radhika G, Vijayalakshmi P, et al. (2010) Editorial: can diabetes/cardiovascular disease epidemic in India be explained, at least in part, by excess grain (rice) intake? Ind J Med Res 131, 369-372.

5. Tripathi B. Charak Samhita of Agnivesa, Part-2, Chikitsasthan; Pramehachikitsa, Chapter 6, Verse 4. Varanasi: Chaukhamba Sanskrit Prakashan, 2001; p. 279
6. Ambikadatta S. Sushrut Samhita of Sushrut, Part-1, Nidansthan; Prameha Nidan, Chapter 6, Verse 6. Varanasi: Chaukhamba Sanskrit Sansthan, 2010; p.326

7. Ambikadatta S. Sushrut Samhita of Sushrut, Part-1, Sutrasthan; Annapanvidhi, Chapter 46, Verse 51. Varanasi: Chaukhamba Sanskrit Sansthan, 2010; p.246

8. Hu EA, Pan A, Malik V, Sun Q. White rice consumption and risk of type 2 diabetes: a meta-analysis and systematic review. BMJ 2012;344: e1454

9. Ambikadatta S. Sushrut Samhita of Sushrut, Part-1, Sutrasthan; Annapanvidhi, Chapter 46, Verse 334. Varanasi: Chaukhamba Sanskrit Sansthan, 2010; p.270

10. Ambikadatta S. Sushrut Samhita of Sushrut, Part-1, Sutrasthan; Annapanvidhi, Chapter 46, Verse 10,11. Varanasi: Chaukhamba Sanskrit Sansthan, 2010; p.242

11. Garde GK. Eartha Vagbhat, Sutrasthan, Annarakshadhyay, Chapter 6, Verse 24. Varanasi: Chaukhamba Surbharti Prakashan, 2012; p.25

12. Van Dam RM. A Global Perspective on White Rice Consumption and Risk of Type 2 Diabetes.Diabetes Care 2020 Nov; 43(11): 2625-2627.

13. Ambikadatta S. Sushrut Samhita of Sushrut, Part-1, Sutrasthan; Annapanvidhi, Chapter 46, Verse 349. Varanasi: Chaukhamba Sanskrit Sansthan, 2010; p.271

14. Ambikadatta S. Sushrut Samhita of Sushrut, Part-1, Sutrasthan; Annapanvidhi, Chapter 46, Verse 350. Varanasi: Chaukhamba Sanskrit Sansthan, 2010; p.271

15. Garcia MC, Benassi MT, Soares M. Physicochemical and sensory profile of rice bran roasted in the microwave. Ciênc. Technol. Aliment., Campinas, 32(4): 754761, out.-dez. 2012

16. Sharma P, Sharma G. Kaiyadev Nighantu, Krutanna Varga, Chapter 5, Verse 7. Varanasi: Chaukhamba Orientalia, 2017; p. 402

17. Govind Das. Bhaishajyaratnavali of Shri Govind Das, Grahanirogchikitsaprakarnam, Chapter 8, Verse 32. Varanasi: Chaukhamba Prakashan, 2018; p.243

18. Sharma P, Sharma G. Kaiyadev Nighantu, Krutanna Varga, Chapter 5, Verse 1. Varanasi: Chaukhamba Orientalia, 2017; p. 401

19. Kontum M. A traditional way of rice preparation with benefits for Arthritis and musculoskeletal disorders. J Ayurveda Integr Med. 2010 Oct-Dec; 1(4): 241-242.

20. Boers HM, Hoorn JS, Mela DJ. A systematic review of the influence of rolice characteristics and processing methods on postprandial glycaemic and insulinemic responses. Br J Nutr. 2015 Oct 14; 114(7): 1035-1045.

21. Tripathi B. Charak Samhita of Agnivesa, Part-2, Chikitsasthan; Pramehachikitsa, Chapter 6, Verse 20. 
Varanasi: Chaukhamba Sanskrit Prakashan, 2001; p.286.

22. Kim MH, Lee HJ. The effect of Pressure or Non-Pressure-Cooked Rice on Glucose Response and Satiety in Healthy Korean Women. Current Developments in $\mathrm{Nu}-$ trition, Volume 4, Issue Supplement_2, June 2020, Page 758.

\section{Source of Support: Nil \\ Conflict of Interest: None Declared}

How to cite this URL: Patil KH et al: Classical Concept Of Cooking Rice: A Systematic Review. International Ayurvedic Medical Journal \{online\} 2021 \{cited August 2021\} Available from:

http://www.iamj.in/posts/images/upload/1728 1732.pdf 